Review: The Antarctic

Author(s): C. R. M.

Review by: C. R. M.

Source: The Geographical Journal, Vol. 26, No. 6 (Dec., 1905), pp. 665-666

Published by: geographicalj

Stable URL: http://www.jstor.org/stable/1776075

Accessed: 26-06-2016 20:32 UTC

Your use of the JSTOR archive indicates your acceptance of the Terms \& Conditions of Use, available at

http://about.jstor.org/terms

JSTOR is a not-for-profit service that helps scholars, researchers, and students discover, use, and build upon a wide range of content in a trusted digital archive. We use information technology and tools to increase productivity and facilitate new forms of scholarship. For more information about JSTOR, please contact support@jstor.org.

The Royal Geographical Society (with the Institute of British Geographers), Wiley are collaborating with JSTOR to digitize, preserve and extend access to The Geographical Journal 
section of the Zulu race. But Mr. Stow had not concluded his work evidently at the time of his death, for although he treats with such fulness of the Sechuanaspeaking people and of the Damara and Ovampo, he sass nothing of Zulu-Kaffir stock or of the (to him unknown) Makaranga people south of the Zambezi, who perhaps constitute the third Bantu element in Southern Africa.

But the book is one to which it is impossible to do full justice in a review. Would that there were more Stows in the African world to produce such splendid studies of vanishing and altering peoples!

H. H. Johnston.

\section{POLAR REGIONS.}

\section{The Antarctic.}

The Story of Exploration, edited by Dr. J. Scott Keltie: 'The Siege of the South Pole.' 70 Illustrations and large Coloured Map. By H. R. Mill, LL.D., D.sc. London: Alston Rivers. 1905.

Dr. Mill's history of southern voyages is a much-needed and very welcome book. The Arctics had Sir John Barrow's two volumes of chronological history, and Mr. Shillinglaw's work came out just before we sailed. But they were dull reading, incomplete, and often inaccurate. We preferred the original texts. Thus warned, we supplied our Antarctic Expedition with the published works of Ross and Weddell; we printed Captain Davis's charming letter to his sister, and embodied the texts of Biscoe, Balleny, Dumont D'Urville, and Wilkes in the 'Antarctic Manual.' Actual students of the subject will turn to these fountain-heads; yet they will also have to use Dr. Mill's book for information which cannot be found so easily elsewhere. His chapter on the American sealers, a very obscure subject, is valuable and interesting. Dr. Mill has here brought together much information which would be vainly sought for, in so compact a form, elsewhere. He appears to be indebted, to some extent, to Mr. Balch. It is a pity, however, that so much space should be wasted on Captain Morrell. Dr. Mill has done a still greater service in his chapter on the voyage of Bellingshausen. Until quite lately the work of this eminent explorer was only accessible in the Russian language, although we have long had the use of his maps. The first coral island ever seen by the present writer was named after Lazareff, the second in command of Bellingshausen's expedition; so that we have had the maps showing the track for many years, but not the narrative. At length, in 1902, an abstract was published at Leipzig. It is nearly a complete German translation. We owe to Dr. Mill the first full account of Bellingshausen's voyage in English, and, as the complement of Captain Cook's Antarctic voyage, it is both important and interesting.

Dr. Mill's record of all the other voyages is complete, and well arranged; while the author deserves great praise for a diligent and painstaking accuracy in every detail, which enhances the value of the work, and gives confidence in using it. Thus the Antarctic student is furnished, not only with a reliable book of reference, but also with valnable information which he could not well find elsewhere.

But we hope that the book will serve a still more valuable object. It is written in a most agreeable style, and some parts of the story are quite fascinating. It is most desirable that it should be widely read, and the literary ability of the author gives every promise that it will be popular. W sincerely trust that this will be the case, and that the reading public will thus become so well acquainted with the work that has been achieved, that it will take an intelligent interest in what remains to be done.

Dr. Mill's book will show how much remains. One who rises from its perusal 
must do so with a feeling of surprise at the title-'Siege of the South Pole.' With the exception of the expeditions of Sir James Ross and Captain Scott, there has not only been no siege of the south pole, but barely an attempt to go south at all within the Antarctic Regions. There have been various reconnaissances of the Antarctic Circle, usually at a respectful distance to the north. Some of the voyages described by Dr. Mill have never reached the Antarctic Regions at all; others have just crossed the circle.

It is like calling a cruise to Hammerfest a siege of the north pole. Weddell and Bruce have been furthest, making summer cruises in the Weddell sea, and Bruce has furnished us with a valuable series of soundings. But the real work begins where they left off. We regret to see that Dr. Mill is in favour of consultative committees, stations far north of the Antarctic Circle, and another cruise round the threshold. Surely he cannot continue to call this a "Siege of the South Pole'! It is to be hoped that there will be no more committees, and no more pottering round the Antarctic Circle. Future voyagers must cross it, if they call their voyages Antarctic, as the very beginning of their work. There are several routes for resolute men who know their business. The next will be down the east coast of Graham's Land. But the course is sou'ri.

In conclusion, we congratulate Dr. Mill on the production of a book which will be of lasting value, and which is calculated to do lasting good to a great cause.

C. R. M.

\section{'Two Years in the Antarctic.' By Albert B. Armitage, Lieut. R.N.R.}

London: Edward Arnold. 1905.

This unpretending narrative of the National Antarctic Expedition by Lieut. Armitage follows the larger and more complete work of his chief, with whose generous consent the present volume appears. Licut. Armitage is an officer of great merit. He was mentioned to us by the chairman of the company he serves, as an officer who would prove useful in many ways. This indeed was the case. Armitage had experience in the navigation of polar ice, in Arctic sledge-travelling, and in taking scientific observations. He is a practical navigator, a judicious manager of men, and a good messmate. He proved himself to be staunchly loyal.

Immediately on his appointment, he entered into the spirit of the work most zealously, and sent in an exhaustive list of sledge equipment and clothing, with valuable notes. Captain Scott used his services to proceed to Norway and procure all the gear for sledging, and see that everything was properly made and fitted. Besides his work as navigator, Armitage had charge of the magnetic observations at sea.

The reader will expect an interesting narrative from such a man, and he will not be disappointed. Throughout we see that Armitage liked and appreciated his work, liked his companions, and was liked by them. He was one of a very happy company. Often humorous, never dull, the story as told by our polar veteran ought to find many interested readers.

C. R. M.

\section{THE MONTHLY RECORD.}

\section{EUROPE.}

German Sea Fisheries.-A comprehensive account of German sea-fishing is given in a recent Consular Report (Misc. Series, No. 636). The gross tonnage of the German fishing fleet in 1904 was 47,860 , a marked increase on previous 